\title{
Research Paper: Histological and Biochemical Alterations in the Superior Colliculus and Lateral Geniculate Nucleus of Juvenile Rats Following Prenatal Exposure to Marijuana Smoke
}

Grace Akingbade $^{1 *}$ (D), Omamuyovwi Ijomone ${ }^{1}$, Sunday Adelakun $^{1}$, Bernard Enaibe $^{2}$

1. Department of Human Anatomy, School of Health and Health Technology, Federal University of Technology, Akure, Nigeria. 2. Department of Anatomy, Faculty of Basic Medical Sciences, College of Health Sciences, University of Ilorin, Ilorin, Nigeria.

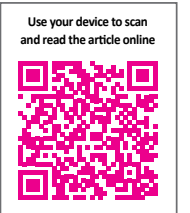

Citation Akingbade, G., Ijomone, O., Adelakun, S., \& Enaibe, B. (2021). Histological and Biochemical Alterations in the Superior Colliculus and Lateral Geniculate Nucleus of Juvenile Rats Following Prenatal Exposure to Marijuana Smoke. Basic and Clinical Neuroscience, 12(6), 745-758. http://dx.doi.org/10.32598/bcn.2021.1701.1

http://dx.doi.org/10.32598/bcn.2021.1701.1

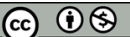

Article info:

Received: 14 Feb 2019

First Revision: 20 Jul 2019

Accepted: 28 Aug 2019

Available Online: 01 Nov 2021

Keywords:

Marijuana, Superior colliculus, Lateral geniculate nucleus, Oxidative damage, Prenatal exposure

\begin{abstract}
A B S T RA C T
Introduction: Prenatal exposure to Marijuana $(\mathrm{MJN})$ has been associated with various brain deficits. The main activity in marijuana, $\Delta 9$-Tetrahydrocannabinol (THC), crosses the placenta and affects fetal brain development. Despite this, marijuana remains a commonly abused substance among pregnant women. The current study examined the histological and biochemical changes in the Superior Colliculus (SC) and Lateral Geniculate Nucleus (LGN) in rat brains prenatally exposed to marijuana.
\end{abstract}

Methods: Four groups of pregnant rats ( $\mathrm{n}=5$ rats/group) were exposed to the smoke of $10 \mathrm{~g}$ / $\mathrm{kg}$ marijuana at various days during their gestational period, with a group (control), i.e., not exposed. After parturition, the litters from each group were sacrificed by cervical dislocation on postnatal days 7,14 , and 21 ; the superior colliculi and lateral geniculate nuclei were excised. Tissue sections were prepared for histological studies using Haematoxylin and Eosin stains. Biochemical studies were performed on alkaline phosphatase, acid phosphatase, lactate dehydrogenase, and glucose-6-phosphate dehydrogenase activity levels. The histological and biochemical analyses of tissues were performed.

Results: Prenatal exposure to marijuana resulted in spontaneous abortion and affected neuronal morphology in the SC and LGN of the progeny. Furthermore, the levels of enzyme activities were altered following maternal exposure to $\mathrm{MJN}$.

Conclusion: These data suggested that histological changes in the SC and LGN were associated with oxidative damage.

\footnotetext{
* Corresponding Author: Grace Akingbade, PhD.

Address: Department of Human Anatomy, School of Health and Health Technology, Federal University of Technology, Akure, Nigeria. Tel: +234 (806) 6118509

E-mail: gtakingbade@futa.edu.ng
} 


\section{Highlights}

- Prenatal exposure to marijuana smoke in early gestation induced spontaneous abortion.

- Prenatal exposure to marijuana smoke-induced damage to the visual pathway in the progeny.

- Prenatal exposure to marijuana-induced histological changes in juvenile rats' superior colliculus and lateral geniculate nucleus.

- Prenatal exposure to marijuana smoke resulted in biochemical alterations in juvenile rats' superior colliculus and lateral geniculate nucleus.

\section{Plain Language Summary}

Marijuana is the most widely used psychoactive substance in the western world, consumed for recreational, medicinal, and spiritual purposes. Although marijuana consumption by pregnant women has been linked with neurodevelopmental consequences, little is known of its effect on the visual pathway of the progeny. We examined juvenile rats using the rat model, the effect of prenatal exposure to marijuana smoke on the superior colliculus and lateral geniculate body (regions of the brain involved in visual information processing). Our result reveals that marijuana use in early gestation induces spontaneous abortion. Also, prenatal exposure to marijuana smoke produced histological changes in the brain mentioned above regions involved in visual information of the progeny. Our findings also include biochemical alterations in these regions. Hence, we highlight the damaging effects of marijuana smoke on the developing brain, specifically the superior colliculus and lateral geniculate nucleus, i.e., involved in visual information processing, of juvenile rats following prenatal exposure.

\section{Introduction}

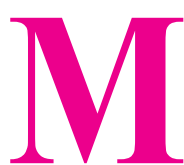

arijuana $(\mathrm{MJN})$ is among the most commonly abused substances. Its consumption constitutes a severe health concern because it could exert deleterious consequences on the progeny if consumed during pregnancy. These adverse consequences include anxiety, depression, psychosis risk, and cognitive and social impairments (Volkow, Baler, Compton, \& Weiss, 2014). The placenta acts as a barrier between maternal and fetal circulation. Cannabinoids are the significant components of MJN; however, they can cross this barrier into fetal circulation (Abel, 1980). $\Delta 9$-Tetrahydrocannabinol (THC) is the most prominent psychoactive compound found in marijuana. Neurodevelopmental consequences observed in animal models due to its manipulation prove its importance in brain development (de Salas al., 2015).

The two most robust pathways linking the eye to the brain are those projecting to the LGN and the SC (Goodale \& Milner, 2004). The Superior Colliculus (SC), a visual relay center, transforms visual and non-visual sensory impulses into motor commands that control orienting behaviors (Wurtz \& Goldberge, 1972; Doubell, Skaliora,
Baron, King, \& King, 2003). Thus, the SC is part of brain areas involved in visual-spatial attention, allowing animals to base decisions on relevant environmental stimuli and suppress irrelevant signals (Krauzlis et al., 2013). The Lateral Geniculate Nucleus (LGN) is often promoted as the prototype dorsal thalamic nucleus and represents the central thalamic relay station for visual information in mammals (Sherman \& Guillery, 2004). Moreover, $70 \%$ $80 \%$ of neurons in the LGN consists of Thalamocortical (TC) neurons whose function is the transmission and processing of sensory information from the retinal ganglion cells to the primary cortex (Leist et al., 2016).

Endogenous cannabinoids are crucial for proper fetal development, while exogenous cannabinoids, like MJN, disrupt proper development in utero (El Marroun et al., 2009). THC can be secreted in breast milk to feed the newborn during breastfeeding (Hutchings, Martin, Gamagaris, Miller, \& Fico, 1989). It was revealed that prenatal use of MJN resulted in functional deficits such as inattentiveness, impulsivity, deficits of learning and memory, and a deficiency in aspects of executive functions (Karila, Cazas, Danel, \& Reynaud, 2006). Human studies revealed that newborns exposed to MJN encounter sleep disturbances, up to age 3 years, and a shorter, high-pitched cry (Dahl, Scher, Williamson, Robles 1995; 
Lester \& Dreher, 1989). Altered responses to visual stimuli and increased startles and tremors were noted in newborns exposed to MJN, with some such symptoms lasting for at least 30 days after birth (Fried \& Makin, 1987). In animal models, exposed offspring showed reduced body weight at birth (Abel, Bush, Dintcheff, \& Ernst, 1981). As with humans, young rats exposed to THC throughout pre- and postnatal development had increased ultrasonic vocalizations (cries) when isolated, indicative of increased anxiety and potentially analogous to increased irritability in human infants (Trezza et al., 2008). In this same study, rats suggested deficits in social behaviors during adolescence and elevated anxiety in adulthood. The increased locomotor activity has been demonstrated; however, others suggested no changes in locomotion or significant hypoactivity (Mereu et al., 2003; Schneider, 2009).

Developing an embryo could be highly vulnerable to specific environmental agents with negligible or nontoxic effects in adult individuals. Awareness that prenatal exposure to certain drugs and chemicals can cause developmental disruptions offers the opportunity to prevent some congenital anomalies (Moore \& Persaud, 2010). A previous study revealed that marijuana smoke induces damage in the brain and the visual pathway in adult animal models (Patrick, Krishnan, Vohs, \& O'Donnell, 2006). In visual perception, visual information from the retina is processed and transmitted to the primary visual cortex by the LGN (Mather, 2017). SC plays a central role in visual-spatial attention by controlling orienting movements of the eyes and head (Krauzlis et al., 2017). Therefore, damage to the visual pathway via the $\mathrm{SC}$ and LGN can result in visual impairment (Eric, 2015) and attention deficit (Prendergast, 1998). The current study investigated histological and biochemical alterations in the visual relay stations of the brain (SC \& LGN) following prenatal exposure to MJN.

\section{Methods}

\section{Animal care}

In total, 25 female rats and 10 male rats weighing 170 $-220 \mathrm{~g}$ were procured and housed in the animal holding of the Department of Anatomy, University of Ilorin, Ilorin, Nigeria. The animals were housed in individual cages under the standard natural photoperiodic condition of 12 hours of darkness and twelve hours of lightness (D:L; 12:12h dark/light cycle) at room temperature $\left(25-32^{\circ} \mathrm{C}\right)$ and humidity of $50 \%-55 \%$. Their cages were cleaned every day. Animals in all groups were allowed access to standard laboratory rat chow and water ad li- bitum. All experimental protocols were in strict accordance with the guidelines for animal research, as detailed in the Guide for the Care and Use of Laboratory Animals (National Research Council, 2011), and approved by the local Institutional Research Committee.

\section{Mating and grouping of animals}

A vaginal smear test was performed daily before mating. Mating was performed by natural copulation. Marcoides' method of vaginal smear was carried out to confirm mating (Marcondes, Biachi, \& Tanno, 2002). Then, the day following mating was obtained as day zero (0) of pregnancy. Pregnant rats were randomly divided into five groups $(\mathrm{n}=5$ rats/group) $-\mathrm{a}$ control and 4 treatment groups.

\section{Drug administration}

Cannabis sativa was obtained from the Nigeria Drug Law Enforcement Agency, Kwara State command, Nigeria. The leaves and buds of the plant were used to make filtered tip MJN cigarettes containing $10 \mathrm{~g} / \mathrm{kg}$ MJN for smoke exposure to each pregnant rat. Each pregnant rat was exposed to MJN smoke in a closed chamber on various Prenatal Days $(\mathrm{PrN})$ during the 21 days (three weeks) gestational period in rats for four minutes:

Group A (Control): unexposed

Group B: PrN 6 - 8 (first week of gestation)

Group C: PrN 12 - 14 (second week of gestation)

Group D: PrN $19-21$ (third week of gestation)

Group E: PrN 6-21 (throughout gestation)

\section{Exposure system}

As previously described, the pregnant rats were exposed to smoke (Santiago, Fenley, Braga, Cordeiro, \& Cury, 2009). The sidestream smoke was generated by burning $10 \mathrm{~g} / \mathrm{kg}$ MJN in a smoking chamber. Each MJN cigarette was inserted into the cigarette holder on the burner. The marijuana cigarettes were lightened in a glass and left to glow in the compartment, and the produced smoke was drawn into the chamber where the rats were placed only for exposure. The chamber atmosphere was monitored for Carbon Monoxide (CO). A nose mask was employed to protect experimenters from MJN smoke. 


\section{Animal sacrifice}

After parturition, pups from each group ( $\mathrm{n}=5$ pups per group of pregnant rats) were sacrificed by cervical dislocation on Postnatal Days (PND) 7, 14, and 21. The cranium of each litter was opened by mid-sagittal incision, and the whole brain was excised. Next, the superior colliculus and lateral geniculate nucleus were carefully removed. Some of these tissues were fixed in formol calcium for histological techniques. Moreover, some were homogenized in $0.2 \mathrm{M}$ sucrose solution for enzyme studies.

\section{Histology}

Brain samples were fixed in 10\% formol calcium ( $40 \%$ formaldehyde $-100 \mathrm{~mL}$, Calcium chloride $-10 \mathrm{~g}$, Distilled water $-900 \mathrm{~mL}$ ) and processed for routine tissue processing using established protocols (Bancroft \& Gamble, 2008). Digital photomicrographs were obtained from stained slides using a digital microscope (OMAX microscopes, Irvine, CA, USA).

\section{Biochemical assays}

SC and LGN tissues from control and rats prenatally exposed to MJN were separately homogenized in $50 \mathrm{mM}$ of Tris-HCl buffer $(\mathrm{pH}=7.4)$ containing $1.15 \%$ potassium chloride. The homogenate was centrifuged at $10000 \times \mathrm{g}$ for 15 minutes at $4^{\circ} \mathrm{C}$. The supernatant was collected and was subsequently used for total protein estimation. The protein content of the brain homogenate was estimated by the method of Lowry, Rosebrough, Farr, and Randall, (1951) using bovine serum albumin as a standard.

\section{Alkaline phosphatase}

Phenolphthalein monophosphate method using Quimica Clinica Aplicada's kit. One drop of the substrate (phenolphthalein monophosphate) was added to $1.0 \mathrm{~mL}$ of water (Babson, Greely, Coleman, \& Phillips, 1966). It was mixed and incubated at $37^{\circ} \mathrm{C}$ for 5 minutes. The homogenate $(0.1 \mathrm{~mL})$ was added, mixed, and incubated at $37^{\circ} \mathrm{C}$ for 20 minutes. A color $(5.0 \mathrm{~mL})$ developer was added. The initial absorbance was read at a wavelength of $550 \mathrm{~nm}$.

\section{Acid phosphatase}

The acid phosphatase activity in tissue homogenate was assayed using RANDOX Kit (Antrim, UK) (Lohr $\&$ Waller, 1974). The homogenate $(100 \mu \mathrm{L})$ was pipetted into a test tube labeled test, and $100 \mu \mathrm{L}$ of distilled water was pipette into a test tube labeled blank. Acid phosphatase buffer substrate $(0.5 \mathrm{~mL})$ was added to each tube, and the mixtures were incubated at $37^{\circ} \mathrm{C}$ for 30 minutes.
Thereafter, $5.0 \mathrm{~mL}$ of $0.02 \mathrm{M} \mathrm{NaOH}$ were added to the combinations. The absorbance of the test was read at $405 \mathrm{~nm}$ in a spectrophotometer.

\section{Lactate dehydrogenase}

The assay for this enzyme was done using AGAPPE DIAGNOSTIC LTD Kit (Wei Bhaar, Grossau, \& Faderal, 1975). The working reagent $(100 \mathrm{~mL})$ was mixed with $10 \mathrm{ml}$ of the sample. The mixture was incubated at $37^{\circ} \mathrm{C}$ for 1 minute. The change in absorbance per minute was measured for 3 minutes $(\Delta \mathrm{OD} / \mathrm{min})$.

\section{Glucose-6-phosphate dehydrogenase}

The activity of G6PDH in tissue homogenate was assayed using RANDOX Kit (Lohr \& Waller, 1974). The activity of G6PDH in the tissues was assayed at $37^{\circ} \mathrm{C}$ against air at a wavelength of $340 \mathrm{~nm}$ and a light path of $1 \mathrm{~cm}$. The homogenate $(0.5 \mathrm{~mL})$ was mixed with $2.00 \mathrm{~mL}$ of the first and $0.10 \mathrm{~mL}$ of the second reagent. The mixture was then incubated for 10 minutes at $37^{\circ} \mathrm{C}$. After that, $0.05 \mathrm{~mL}$ of the third reagent was added and mixed. The initial absorbance was read after 1,2 , and 3 minutes.

The obtained data were expressed as Mean \pm SEM. Data comparisons were performed using repeated-measures Analysis of Variance (ANOVA). GraphPad PRISM 5 (V. 5.03, GraphPad Software, San Diego, CA, USA) was the statistical package used for data analysis. Statistical significance was set at $\mathrm{P}<0.05$.

\section{Results}

Spontaneous abortion

Spontaneous abortion and fetal resorption were observed in rats exposed to $10 \mathrm{~g} / \mathrm{kg}$ MJN smoke on PrN 6-8 and PrN 6-21. Bloodstain was detectedn in the cages and vagina of pregnant rats in this group. There was no live or dead litter recovered from these groups.

\section{Effect on SC and LGN histomorphology}

Neuronal degeneration is characterized by dense shrunken cytoplasm, neuronal enlargement, vacuolations, and pyknotic nuclei (Carliss, Radovsky, Chengelis, O'Neill, \& Shuey, 2007; Garman, 2011). In the controls, findings revealed numerous neurons with preserved architecture in both SC and LGN (Figures 1 and 2). In the treatments groups $\mathrm{C}$ ( $\operatorname{PrN} 12-14)$ and $\mathrm{D}$ (PrN 19-21), neurons present anomalies in the form of shrunken cytoplasm, vacuolations, and enlargement on postnatal day 7. On PNDs 14 and 21, effects appear more severe in the treatment groups. 

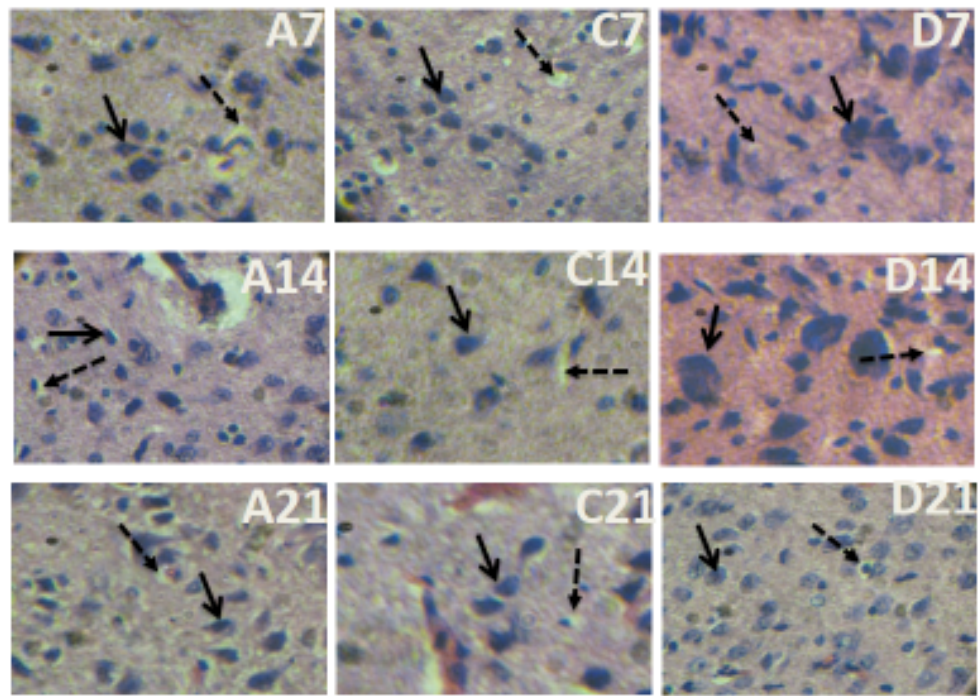

NEUR:SCIENCE

Figure 1. A photomicrograph of a section of the SC of Groups A, C, and D on Days 7, 14, and 21. H\&E x400

Observe that neurons in the treatment groups C and D have a large, rounded nucleus (arrows) compared with group A (control) Moreover, observe large vacuolations (dashed arrows) within the cytoplasm in the treatment groups compared with the control group.

\section{Enzyme studies}

\section{Alkaline phosphatase (ALP)}

The repeated-measures ANOVA data of activity level of Alkaline phosphatase in superior colliculus (Figure 3) indicated significant interaction $\left(\mathrm{F}_{436}=1694 ; \mathrm{P}<0.0001\right)$, group factor $\left(\mathrm{F}_{2,36}=3841 ; \mathrm{P}<0.0001\right)$ and time factor $\left(\mathrm{F}_{2,36}=2118 ; \mathrm{P}<0.0001\right)$. Post-test analysis revealed a significant increase $(\mathrm{P}<0.001)$ in ALP in groups treated with $10 \mathrm{~g} / \mathrm{kg} \mathrm{MJN}$ on PrN 12-14, at postnatal days 14 and 21, compared to the controls. Additionally, compared to the controls, $10 \mathrm{~g} / \mathrm{kg}$ MJN on PrN 19-21 revealed a significant increase $(\mathrm{P}<0.001)$ in ALP at postnatal days 7, 14, and 21. Furthermore, $10 \mathrm{~g} / \mathrm{kg}$ MJN on PrN 19-21 suggested significantly higher $(\mathrm{P}<0.001)$ ALP levels compared to $10 \mathrm{~g} / \mathrm{kg}$ MJN on PrN 12-14 at postnatal days 7 and 21.

In the lateral geniculate nucleus, data analysis of the activity level of Alkaline phosphatase (Figure 7) revealed significant interaction $\left(\mathrm{F}_{4,36}=2207 ; \mathrm{P}<0.0001\right)$, group factor $\left(\mathrm{F}_{2,36}=7190 ; \mathrm{P}<0.0001\right)$, and time factor $\left(\mathrm{F}_{2,36}=4812\right.$;
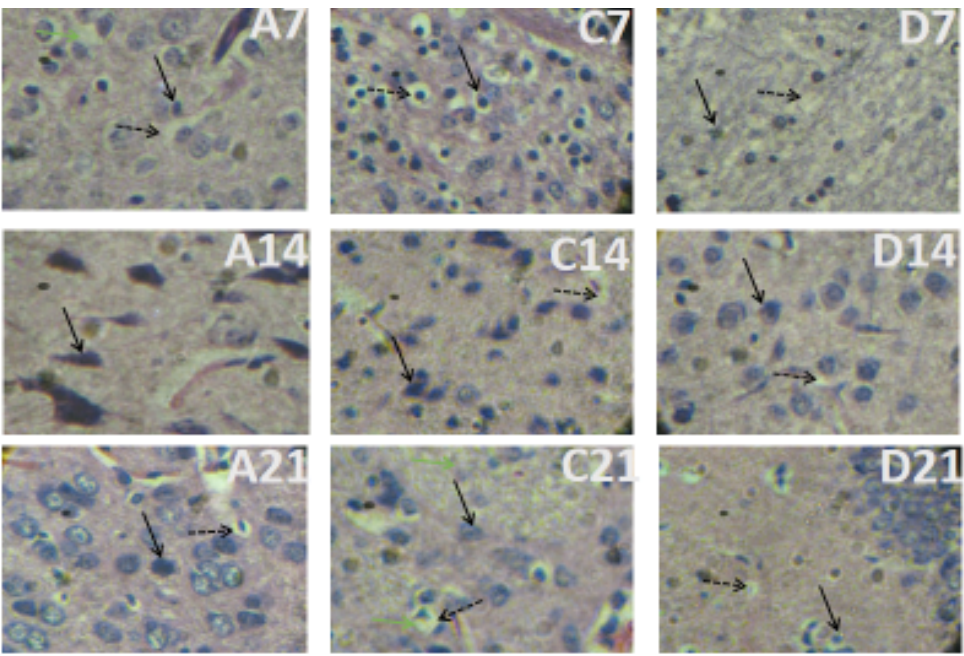

NEUROSCIENCE

Figure 2. A photomicrograph of a section of the LGN of Groups A, C, and D on Days 7, 14, and 21, H\&E x400

Observe that neurons in the treatment groups $\mathrm{C}$ and $\mathrm{D}$ have a large, rounded nucleus (arrows) compared with group A (control) Also, observe large vacuolations (dashed arrows) within the cytoplasm in the treatment groups compared with the controls. 

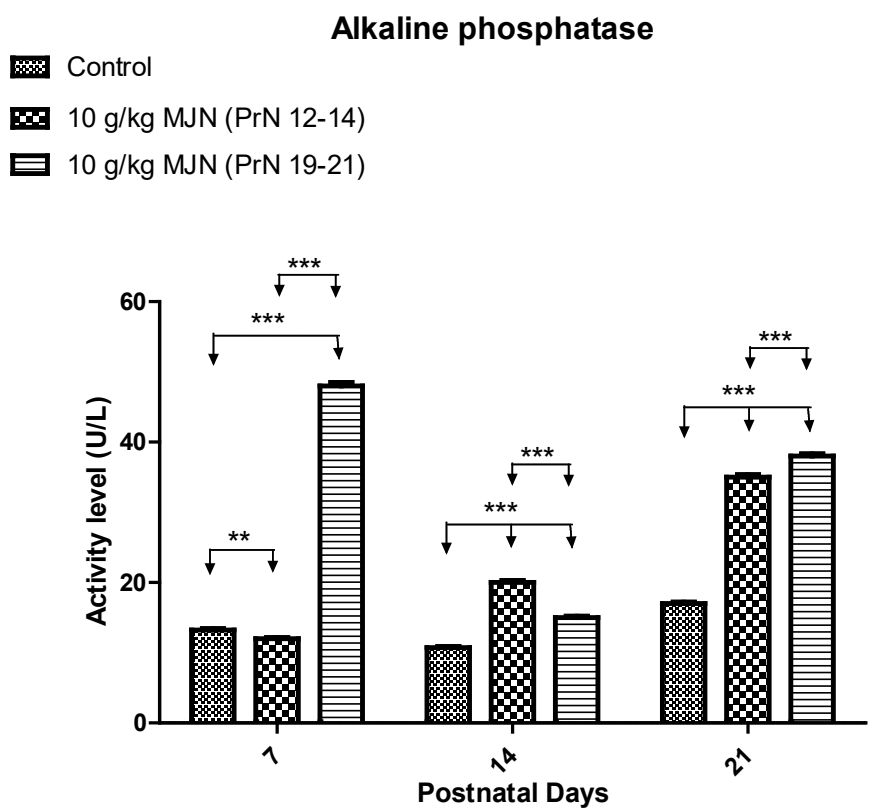

NEUR SCIENCE

Figure 3. The effect of prenatal exposure to MJN $(10 \mathrm{~g} / \mathrm{kg})$ smoke on the activity of ALP in the SC of developing Wistar rats

Values are expressed as Mean \pm SEM. ${ }^{* *} \mathrm{P}<0.01,{ }^{* * *} \mathrm{P}<0.001$, repeated-measures ANOVA followed by Bonferroni post-test.

$\mathrm{P}<0.0001]$. In the post-test analysis, there is a significant increase $(\mathrm{P}<0.001)$ in ALP in groups treated with $10 \mathrm{~g} /$ $\mathrm{kg}$ MJN on PrN 12-14 at postnatal days 14 and 21, compared to the control group. Furthermore, on postnatal days 7, 14, and 21, groups treated with $10 \mathrm{~g} / \mathrm{kg} \mathrm{MJN}$ of PrN 19-21 indicated a significant increase $(\mathrm{P}<0.001)$ in ALP. Furthermore, compared to $10 \mathrm{~g} / \mathrm{kg} \mathrm{MJN}$ on $\mathrm{PrN}$
$12-14$, the post-tests analysis revealed significantly higher $(\mathrm{P}<0.001)$ ALP levels in groups treated with $10 \mathrm{~g} / \mathrm{kg} \mathrm{MJN}$ on PrN 19-21 at postnatal days 7 and 21.

Acid phosphatase

control
$10 \mathrm{~g} / \mathrm{kg}$ MJN (PrN 12-14)

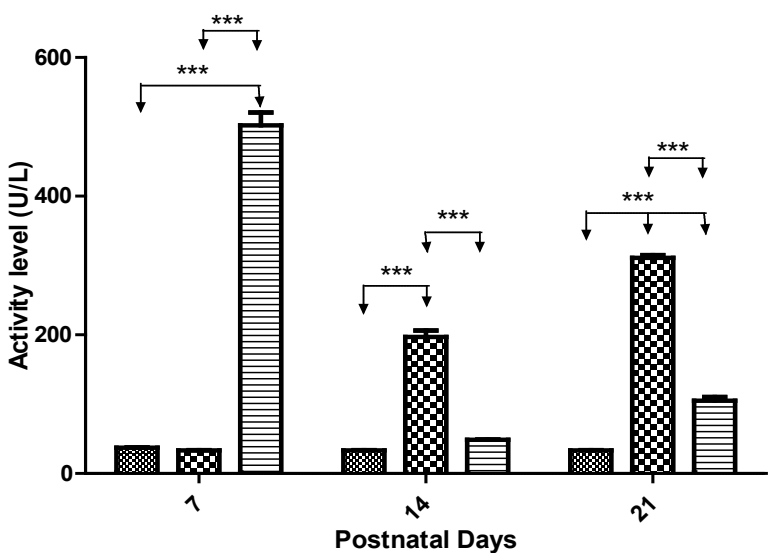

NEUR:SCIENCE

Figure 4. The effects of prenatal exposure to MJN (10 g/ kg) smoke on ACP activity in the SC of developing Wistar rats Values are expressed as Mean \pm SEM. *** $\mathrm{P}<0.001$, repeated-measures ANOVA followed by Bonferroni post-test. 


\section{Lactate dehydrogenase}

Control

$\infty 10 \mathrm{~g} / \mathrm{kg}$ MJN (PrN 12-14)

ஏ $10 \mathrm{~g} / \mathrm{kg}$ MJN (PrN 19-21)

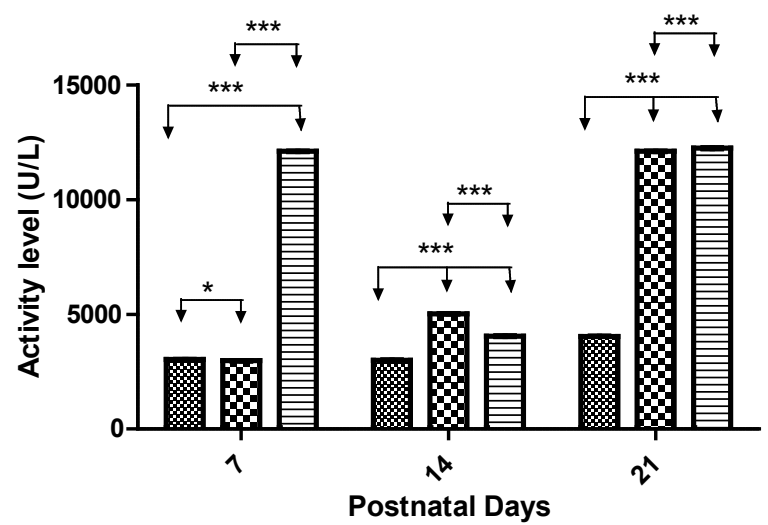

NEUR SCIENCE

Figure 5. The effect of prenatal exposure to MJN $(10 \mathrm{~g} / \mathrm{kg})$ smoke on the activity of LDH in the SC of developing Wistar rats

Values are expressed as Mean \pm SEM. ${ }^{*} \mathrm{P}<0.05,{ }^{* * *} \mathrm{P}<0.001$, repeated-measures ANOVA followed by Bonferroni post-test.

\section{Acid Phosphatase (ACP)}

In the superior colliculus, repeated-measures ANOVA data of the activity level of Acid phosphatase (Figure 4) revealed significant interaction $\left(\mathrm{F}_{4,36}=682.0 ; \mathrm{P}<0.0001\right)$, group factor $\left(\mathrm{F}_{2,36}=525.7 ; \mathrm{P}<0.0001\right)$, and time factor $\left(\mathrm{F}_{2,36}=134.9 ; \mathrm{P}<0.0001\right)$. Post-test analysis revealed a significant increase $(\mathrm{P}<0.001)$ in $\mathrm{ACP}$ level in groups treated with $10 \mathrm{~g} / \mathrm{kg} \mathrm{MJN}$ on PrN 12-14, at postnatal days 14 and 21, compared to control. The group treated with $10 \mathrm{~g} / \mathrm{kg}$ MJN on PrN 19-21 also indicated a significant increase $(\mathrm{P}<0.001)$ in ACP compared to control. However, $10 \mathrm{~g} / \mathrm{kg}$ MJN on PrN 19-21 suggested signifi-

Glucose-6-phosphate dehydrogenase
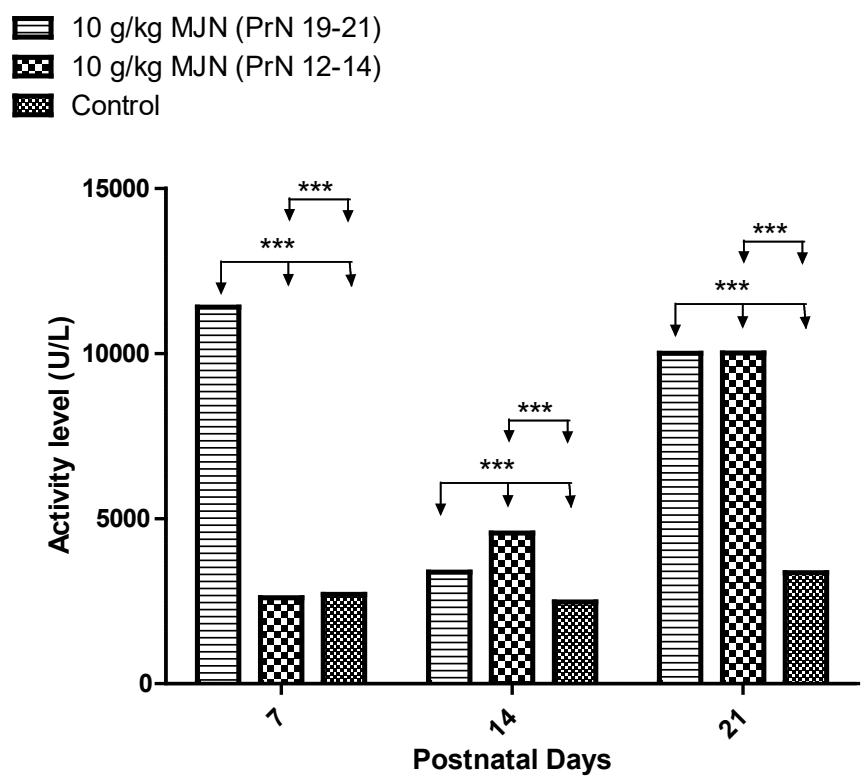

NEUR:SCIENCE

Figure 6. The effect of prenatal exposure to MJN $(10 \mathrm{~g} / \mathrm{kg})$ smoke on the activity of G6PDH in the SC of developing Wistar rats Values are expressed as Mean \pm SEM. ${ }^{* *} \mathrm{P}<0.001$, repeated-measures ANOVA followed by Bonferroni post-test. 


\section{Alkaline phosphatase}

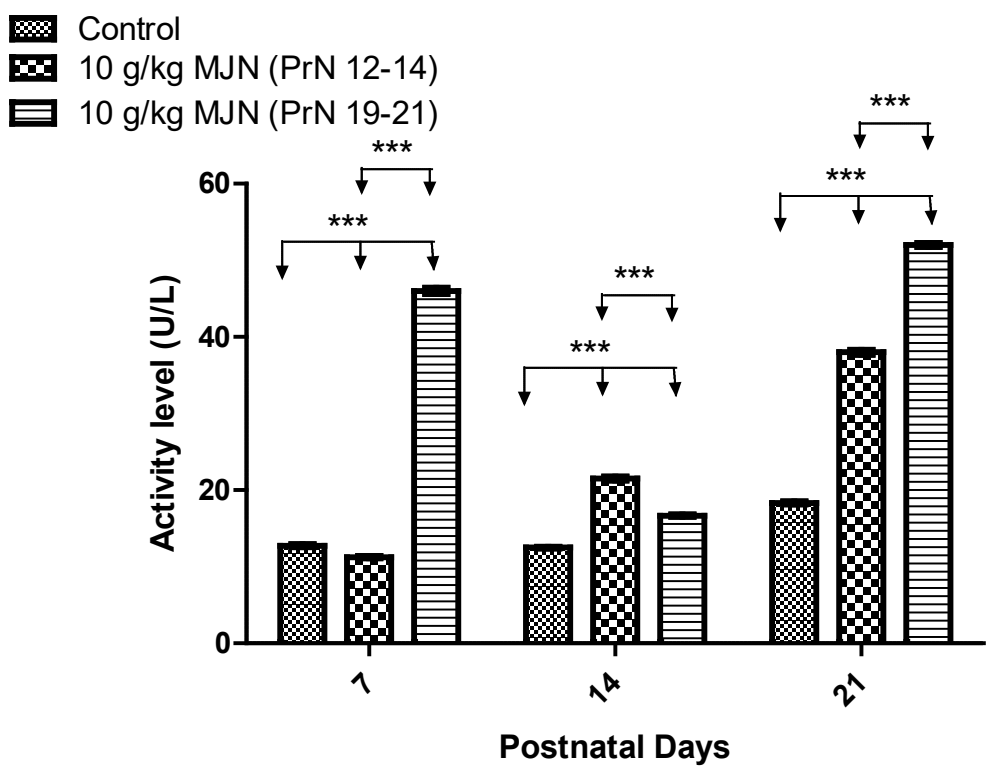

NEUR SCIENCE

Figure 7. The effect of prenatal exposure to MJN $(10 \mathrm{~g} / \mathrm{kg})$ smoke on the activity of ALP in the LGN of developing Wistar rats

Values are expressed as Mean \pm SEM. *** $\mathrm{P}<0.001$, repeated-measures ANOVA followed by Bonferroni post-test.

cantly lower $(\mathrm{P}<0.001)$ ACP levels than $10 \mathrm{~g} / \mathrm{kg} \mathrm{MJN}$ on PrN 12-14 at postnatal days 14 and 21. The repeatedmeasures ANOVA results revealed significant interaction $\left(\mathrm{F}_{4,36}=7319 ; \mathrm{P}<0.0001\right)$, group factor $\left(\mathrm{F}_{2,36}=5235\right.$; $\mathrm{P}<0.0001)$, and time factor $\left(\mathrm{F}_{2,36}=1448 ; \mathrm{P}<0.0001\right)$ in the activity level of ACP (Figure 8) in the lateral geniculate nucleus. Post-test analysis data suggested a significantly higher $(\mathrm{P}<0.001)$ ACP level in group treated with $10 \mathrm{~g} / \mathrm{kg}$ MJN on PrN 12-14, at postnatal days 14 and 21 , compared to control. Additionally, the group treated
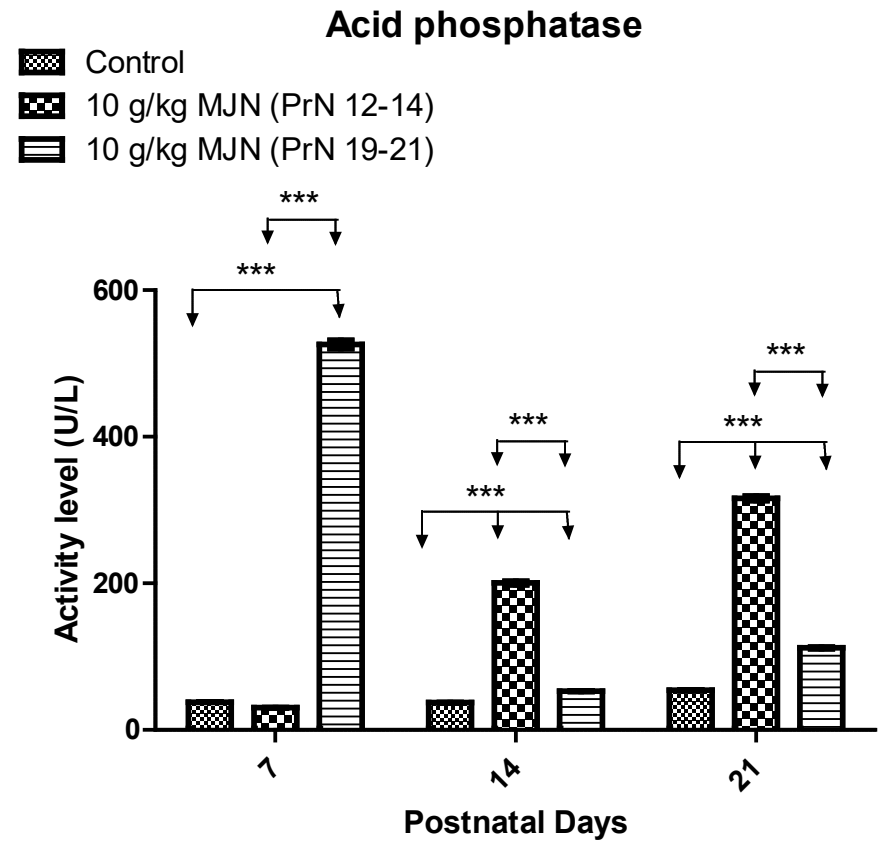

NEUR SCIENCE

Figure 8. The effect of prenatal exposure to MJN $(10 \mathrm{~g} / \mathrm{kg})$ smoke on ACP activity in the LGN of developing Wistar rats

Values are expressed as Mean \pm SEM. *** $\mathrm{P}<0.001$, repeated-measures ANOVA followed by Bonferroni post-test. 


\section{Lactate dehydrogenase}

Control

E0 $10 \mathrm{~g} / \mathrm{kg}$ MJN (PrN 12-14)

口 $10 \mathrm{~g} / \mathrm{kg}$ MJN (PrN 19-21)

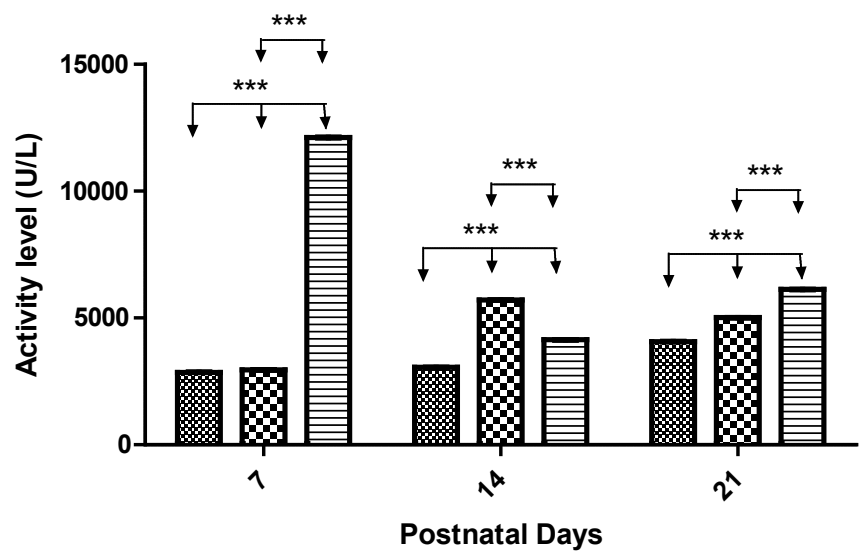

NEUR SCIENCE

Figure 9. The effect of prenatal exposure to MJN $(10 \mathrm{~g} / \mathrm{kg})$ smoke on the activity of LDH in the LGN of developing Wistar rats Values are expressed as Mean \pm SEM. ${ }^{* *} \mathrm{P}<0.001$, repeated-measures ANOVA followed by Bonferroni post-test.

with $10 \mathrm{~g} / \mathrm{kg}$ MJN on PrN 19-21 revealed a significant increase $(\mathrm{P}<0.001)$ in ACP level, compared to control on postnatal days $7,14,21$. The group treated with $10 \mathrm{~g} / \mathrm{kg}$ MJN on PrN 19-21 demonstrated a significant decrease $(\mathrm{P}<0.001)$ in ACP levels, compared to $10 \mathrm{~g} / \mathrm{kg} \mathrm{MJN}$ on PrN 12-14 at postnatal days 14 and 21.

\section{Lactate Dehydrogenase (LDH)}

The repeated-measures ANOVA data of the activity level of lactate dehydrogenase (Figure 5) in superior colliculus revealed significant interaction $\left(\mathrm{F}_{4,36}=98213\right.$; $\mathrm{P}<0.0001)$, group factor $\left(\mathrm{F}_{2,36}=243495 ; \mathrm{P}<0.0001\right)$, and time factor $\left(\mathrm{F}_{2.36}=196873 ; \mathrm{P}<0.0001\right)$. Post-test analysis showed a significantly higher $(\mathrm{P}<0.001) \mathrm{LDH}$ level in the group treated with $10 \mathrm{~g} / \mathrm{kg} \mathrm{MJN}$ on PrN 12-14, compared to the control group at postnatal days 7,14 , and

\section{Glucose-6-phosphate dehydrogenase}

Control

ख $10 \mathrm{~g} / \mathrm{kg}$ MJN (PrN 12-14)

曰 $10 \mathrm{~g} / \mathrm{kg}$ MJN (PrN 19-21)

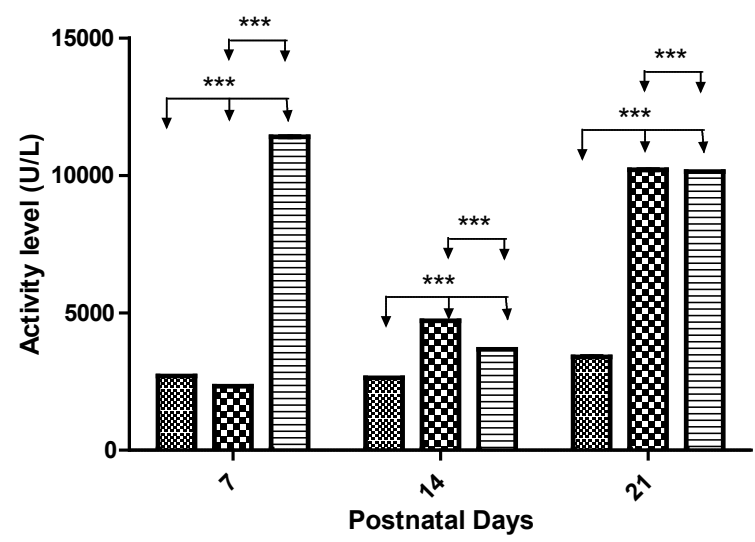

NEUR:SCIENCE

Figure 10. The effect of prenatal exposure to $\mathrm{MJN}(10 \mathrm{~g} / \mathrm{kg})$ smoke on the activity of G6PDH in the LGN of developing Wistar rats

Values are expressed as Mean \pm SEM. ${ }^{* *} \mathrm{P}<0.001$, repeated-measures ANOVA followed by Bonferroni post-test. 
21. Similarly, there is a significant increase $(\mathrm{P}<0.001)$ in LDH level in the group treated with $10 \mathrm{~g} / \mathrm{kg} \mathrm{MJN}$ on PrN 19-21 at postnatal days 7, 14, and 21, compared with the controls. $\mathrm{LDH}$ level also increased significantly $(\mathrm{P}<0.001)$ in the group treated with $10 \mathrm{~g} / \mathrm{kg} \mathrm{MJN}$ on $\mathrm{PrN}$ 19-21, compared to $10 \mathrm{~g} / \mathrm{kg} \mathrm{MJN}$ on PrN 12-14 at postnatal days 7 and 21 .

Analysis of the activity level of LDH (Figure 9) in the lateral geniculate nucleus using repeated-measures ANOVA indicated significant interaction $\left(\mathrm{F}_{4,36}=121269\right.$; $\mathrm{P}<0.0001)$, group factor $\left(\mathrm{F}_{2,36}=186128 ; \mathrm{P}<0.0001\right)$, and time factor $\left(\mathrm{F}_{2,36}=29018 ; \mathrm{P}<0.0001\right)$. Post-test analysis revealed a significant increase $(\mathrm{P}<0.001)$ in $\mathrm{LDH}$ level in the group treated with $10 \mathrm{~g} / \mathrm{kg} \mathrm{MJN}$ on PrN 12-14, compared to the control group at postnatal days 7, 14, and 21 . Moreover, there is a significantly higher $(\mathrm{P}<0.001) \mathrm{LDH}$ level in the group treated with $10 \mathrm{~g} / \mathrm{kg}$ MJN on PrN 1921 at postnatal days 7, 14, and 21, compared with control. Additionally, LDH level in the group treated with $10 \mathrm{~g} / \mathrm{kg}$ MJN on PrN 19-21 also increased significantly $(\mathrm{P}<0.001)$ compared to $10 \mathrm{~g} / \mathrm{kg} \mathrm{MJN}$ on $\mathrm{PrN} 12-14$ at postnatal days 7 and 21 .

\section{Glucose-6-Phosphate Dehydrogenase (G6PDH)}

The repeated-measures ANOVA results of activity level of Glucose-6-phosphate dehydrogenase (Figure 6) in superior colliculus showed significant interaction $\left(\mathrm{F}_{4,36}=1.407 \mathrm{e}+7 ; \quad \mathrm{P}<0.0001\right)$, group factor $\left(\mathrm{F}_{2,36}=3.204 \mathrm{e}+7 ; \mathrm{P}<0.0001\right)$ and time factor $\left(\mathrm{F}_{2,36}=2.041 \mathrm{e}+7 ; \mathrm{P}<0.0001\right)$. Post-test analysis revealed significantly higher significantly $(\mathrm{P}<0.001) \mathrm{G6PDH}$ lev$\mathrm{el}$ in the group treated with $10 \mathrm{~g} / \mathrm{kg}$ MJN on PrN 12-14 on postnatal days 14 and 21, compared to the controls. Additionally, compared to the controls, $10 \mathrm{~g} / \mathrm{kg} \mathrm{MJN}$ on PrN 19-21 indicated a significant increase $(\mathrm{P}<0.001)$ in G6PDH at postnatal days 7, 14, and 21. Furthermore, 10 $\mathrm{g} / \mathrm{kg}$ MJN on PrN 19-21 suggested significantly higher $(\mathrm{P}<0.001) \mathrm{G} 6 \mathrm{PDH}$ levels than $10 \mathrm{~g} / \mathrm{kg} \mathrm{MJN}$ on PrN 1214 at postnatal days 7 and 21 .

In the lateral geniculate nucleus, data analysis using repeated-measures ANOVA of glucose-6-phosphate dehydrogenase (Figure 10) revealed significant interaction $\left(\mathrm{F}_{4,36}=1.511 \mathrm{e}+7 ; \mathrm{P}<0.0001\right)$, group factor $\left(\mathrm{F}_{2,36}=3.405 \mathrm{e}+7 ; \mathrm{P}<0.0001\right)$, and time factor $\left(\mathrm{F}_{2,36}=2.046 \mathrm{e}+7 ; \mathrm{P}<0.0001\right)$ in the activity level of Glucose-6-phosphate dehydrogenase. Post-test analysis indicated a significantly higher $(\mathrm{P}<0.001) \mathrm{G6PDH}$ level in

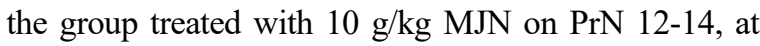
postnatal days 14 and 21, compared to the controls. Additionally, the group treated with $10 \mathrm{~g} / \mathrm{kg} \mathrm{MJN}$ on $\mathrm{PrN}$
19-21 also revealed a significant increase $(\mathrm{P}<0.001)$ in G6PDH level, compared to the control group on postnatal days 7, 14, 21. The group treated with $10 \mathrm{~g} / \mathrm{kg} \mathrm{MJN}$ on PrN 19-21 indicated a significant decrease $(\mathrm{P}<0.001)$ in G6PDH levels, compared to $10 \mathrm{~g} / \mathrm{kg}$ MJN on PrN 1214 at postnatal days 14 and 21 .

\section{Discussion}

In previous experiments using rats, prenatal deaths occur only at high doses and are more probable if the drug administration is relatively early in gestation compared with late in organogenesis (Joneja, 1976; Mantilla-Plata et al., 1975; Gianutsos \& Abbatiello, 1972). This study observed prenatal death in pregnant rats exposed to $10 \mathrm{~g} /$ kg marijuana PrN 6-8 and PrN 6-21.

Marijuana has been reported to have toxic effects on the visual cortex neurons in the rat brain (Patrick et al., 2006) and modulated sensory or perceptual function in the visual pathway (Nava, Cara, Battasi, \& Gessa, 2000). In this study, the SC and LGN of animals that were prenatally exposed to the smoke of MJN presented anomalies in the form of shrunken cytoplasm and vacuolations, which suggest neuronal degeneration. Tijani, Adekomi, Oyesomi, and Fawole (2014) also reported that MJN ingestion caused neurodegeneration in the occipital cortex, lateral geniculate body, and superior colliculus of Wistar rats. On day 7, compared with the control group, neurons in the $\mathrm{SC}$ of animals exposed to $10 \mathrm{~g} / \mathrm{kg}$ marijuana on PrN 12-14 present anomalies in the form of enlargement in size of some neurons, while some others present increased vacuolations that suggest cell death. Neurons also vary in size in the SC of animals exposed to $10 \mathrm{~g} /$ $\mathrm{kg}$ MJN on PrN 19-21. It appears that the substance has a more significant deleterious effect on SC tissues of animals exposed to $10 \mathrm{~g} / \mathrm{kg}$ marijuana on $\operatorname{PrN} 12-14$ than those of animals exposed to $10 \mathrm{~g} / \mathrm{kg}$ MJN on PrN 19-21. Day 14 portrayed a more severe effect of the substance in the SC tissues of animals exposed to $10 \mathrm{~g} / \mathrm{kg}$ marijuana on PrN 12-14 than those exposed to $10 \mathrm{~g} / \mathrm{kg}$ marijuana on PrN 19-21. Some cells in tissues exposed to 10 $\mathrm{g} / \mathrm{kg}$ marijuana on PrN 12-14 appear abnormally larger.

Cells in the treated group also appear less defined. Anomalies are also observable in the treated groups on a postnatal day 21. In the LGN, cells in tissues exposed to $10 \mathrm{~g} / \mathrm{kg} \mathrm{MJN}$ on PrN 12-14 were more severely affected as they appeared shrunken and smaller on day 7 when compared with the control group. Cells of LGB tissue exposed to $10 \mathrm{~g} / \mathrm{kg}$ BW marijuana on PrN 19 - 21 instead appear less developed. Earlier administration of substance destroys cells of LGB; in tissues exposed to 
$10 \mathrm{~g} / \mathrm{kg}$ MJN on PrN 19-21, the situation was growth retardation. The effects appear less severe on day 14, suggesting a structural improvement. Adverse effects are also observed on day 21 for tissues exposed to $10 \mathrm{~g} / \mathrm{kg}$ marijuana on PrN 12-14 and exposed to $10 \mathrm{~g} / \mathrm{kg}$ MJN on PrN 19-21. The above effects agree with the report of Giordano and Costa (2012) that cellular processes involved in neurodevelopment are usually susceptible to the effects of neurotoxic substances, which could result in the different varieties of neurodevelopmental and neurological disorders in postnatal life. Malformations also occur only at high doses and typically are found when cannabinoids are administered for only a few days during organogenesis (Joneja, 1976).

Alkaline phosphatase is an enzyme responsible for transport across cell membranes. Following exposure to smoke, its level of activity increased, causing an alteration in the cellular integrity of the cell membrane and its ability to mediate regular membrane transport (Omotoso, Akinola, Caxton-Martins, Kadir, \& Akinyinka, 2010). Due to this, the leakage of LDH through the membranes could be facilitated (Ho \& Chang, 2006). This study's increase in ALP and LDH levels revealed that prenatal exposure to MJN smoke could have induced oxidative stress in the SC and LGN of developing Wistar rats following maternal exposure. Similarly, Yildz, Ercal, and Armstrong, (1998) revealed that nicotine administration causes an increased LDH activity with an attendant disturbance of cellular integrity.

Acid phosphatase is localized mainly in the lysosome and is considered a marker for lysosomal activities. The activity level of ALP in SC and LGN tissues of animals exposed to $10 \mathrm{~g} / \mathrm{kg} \mathrm{MJN}$ on PrN 12-14 was higher than the controls. The level of ALP in tissues exposed to $10 \mathrm{~g} /$ $\mathrm{kg}$ MJN on PrN 19-210 g/kg greatly fluctuated. It was, however, higher than the control on all days. The same was true of acid phosphatase. The implication is that there is an increase in the function of alkaline and acid phosphatases - this should have involved degradation, a major function of lysosomal enzymes. The inference from the above would be that the administered substance had a toxic or deleterious effect that could have led to the death of cells, hence the need for the degradation of cell debris. Furthermore, it could have been (or rather in addition to the first effect) that the enzymes were needed to correct the change caused by the SC tissue by the substance administered.

Glucose-6-phosphate dehydrogenase is the first ratelimiting enzyme of the pentose-phosphate pathway that converts $\alpha$-D-glucose-6-phosphate into D-glucono-1, 5-lactone-6-phosphate, and is involved in the generation of NADPH (Efferth, Schwarz, \& Osieka, 2006). NADPH is required to generate reduced glutathione, i.e., essential for protection against oxidative damage (Efferth et al., 2006). In this study, the levels of G6PDH in SC and LGN tissues of animals exposed to $10 \mathrm{~g} / \mathrm{kg}$ MJN on PrN 12-14 showed abnormal metabolisms as the enzyme's activity level is higher than in the control group serves as a reference. Both tissues exposed to $10 \mathrm{~g} / \mathrm{kg} \mathrm{MJN}$ on $\mathrm{PrN} 19$ 21 portray an abnormal and irregularly rising and falling rate of metabolism, indicating abnormal development. During cellular oxidative stress, whether endogenous in origin or initiated by drugs or chemicals, NADPH is critical for maintaining glutathione in its reduced form, i.e., essential for detoxifying reactive free radicals and lipid hydroperoxidase (Sodeinde, 1992).

\section{Conclusion}

This study revealed that prenatal exposure to MJN smoke-induced spontaneous abortion in early gestation disrupted the visual pathways by inducing neuronal degeneration, possibly via oxidative damage in the SC and LGN of the juvenile rats.

\section{Ethical Considerations}

\section{Compliance with ethical guidelines}

All experimental protocols were in strict accordance with the guidelines for animal research, as detailed in the NIH Guidelines for the Care and Use of Laboratory Animals and approved by the local institutional Research and Ethics Committee.

\section{Funding}

This research did not receive any grant from funding agencies in the public, commercial, or non-profit sectors.

\section{Authors' contributions}

All authors equally contributed to preparing this article.

\section{Conflict of interest}

The authors declared no conflict of interest. 


\section{Refrences}

Abel, E. L., Bush, R., Dintcheff, B. A., \& Ernst, C. A. (1981). Critical periods for marihuana-induced intrauterine growth retardation in the rat. Neurobehavioral Toxicology and Teratology, 3(3), 351-354. [PMID]

Abel, E. L. (1980). Prenatal exposure to cannabis: A critical review of effects on growth, development, and behaviour Behavioral and Neural Biology, 29(2), 137-156. [DOI:10.1016/ S0163-1047(80)90469-0] [PMID]

Babson, L. A., Greely, S. J., Coleman, C. M., \& Phillips, G. D. (1966). Measurement of alkaline phosphatase activity. Clinical Chemistry, 12(8), 482-490. [DOI:10.1093/clinchem/12.8.482] [PMID]

Carliss, R. D., Radovsky, A., Chengelis, C. P., O'Neill, T. P., \& Shuey, D. L. (2007). Oral administration of dextromethorphan does not produce neuronal vacuolation in the rat brain. Neurotoxicology, 28(4), 813-818. [DOI:10.1016/j.neuro.2007.03.009] [PMID]

Dahl, R. E., Scher, M. S., Williamson, D. E., Robles, N., \& Day, N. (1995). A longitudinal study of prenatal marijuana use. Effects on sleep and arousal at age 3 years. Archives of Pediatrices and Adolescent Medicine, 149(2), 145-150. [DOI:10.1001/archpedi.1995.02170140027004] [PMID]

de Salas-Quiroga, A., Díaz-Alonso, J., García-Rincón, D., Remmers, F., Vega, D., \& Gómez-Cañas, M., et al. (2015). Prenatal exposure to cannabinoids evokes long-lasting functional alterations by targeting CB1 receptors on developing cortical neurons. Proceedings of the National Academy of Sciences of the United States of America, 112(44), 13693-13698. [DOI:10.1073/ pnas.1514962112] [PMID] [PMCID]

Doubell, T. P., Skaliora, I., Baron, J., King, A. J., \& King, A. J. (2003) Functional connectivity between the superficial and deep layers of the SC. An anatomical substrate for sensorimotor integration. Journal of Neuroscience, 23(16), 6596-6607. [DOI:10.1523/ JNEUROSCI.23-16-06596.2003] [PMID][PMCID]

Efferth., T., Schwarz, S. M., \& Osieka., R. (2006). Role of Glucose-6- phosphate dehydrogenase for oxidative stress and apoptosis. Cell Death and Differentiation, 13(3), 527-528. [DOI:10.1038/sj.cdd.4401807] [PMID]

El Marroun, H., Tiemeier, H., Steegers, E. A., Jaddoe, V. W., Hoffmann, A., \& Verhulst, F. C. et al. (2009). Intrauterine cannabis exposure affects fetal growth trajectories: The Generation R Study. Journal of the American Academy of Child $\mathcal{E}$ Adolescent Psychiatry, 48(12), 1173-1181. [DOI:10.1097/ CHI.0b013e3181bfa8ee] [PMID]

Eric, H.C. (2015). Visual Pathway. Neuroscience for Kids. www. faculty.washington.edu.

Fried, P. A., \& Makin, J. E. (1987). Neonatal behavioural correlates of prenatal exposure to marihuana, cigarettes and alcohol in a low risk population. Neurotoxicology and Teratology, 9(1), 1-7. [DOI:10.1016/0892-0362(87)90062-6] [PMID]

Garman, H. R. (2011). Histology of the central nervous system. Toxicologic Pathology, 39(1), 22-35. [DOI:10.1177/0192623310389621] [PMID]

Gianutsos, F., \& Abbatiello, E. R. (1972). The effect of pre- nata Cannabis Sativa on maze learning ability in the rat. Psychopharmacologia, 27(2), 117-122. [DOI:10.1007/BF00439370] [PMID]
Giordano, G., \& Costa, L. G. (2012). Developmental neurotoxicity: Some old and new issues. International Scholarly Research Notices, 2012, 814795. [DOI:10.5402/2012/814795] [PMID] [PMCID]

Goodale, M. \& Milner, D. (2004). Sight unseen. Oxford: Oxford University Press, Inc. https:/ / books.google.com/books?id=g_naAA AAMAAJ\&q=Sight + unseen $+2004 \& d q=S i$

Ho, Y., \& Chang, Y. (2006). Neuropharmacology: Regulation of nicotine-induced cyclooxygenase-2 sprotein expression in human gingival fibroblasts. Acta Pharmacologica Sinica, 27(4), 409-413. [DOI:10.1111/j.1745-7254.2006.00286.x] [PMID]

Hutchings, D. E., Martin, B. R., Gamagaris, Z., Miller, N., \& Fico, T (1989). Plasma concentrations of delta-9-tetrahydrocannabinol in dams and fetuses following acute or multiple prenatal dosing in rats. Life Sciences, 44, 697-701. [DOI:10.1016/0024-3205(89)903809] [PMID]

Joneja, M. G. (1976). A study of teratological effects of intravenous, subcutaneous and intragastric exposure to A9-tetrahydrocannabinol in mice. Toxicology and Applied Pharmacology, 36(1), 151162. [DOI:10.1016/0041-008X(76)90035-1]

Karila, L., Cazas, O., Danel, T., \& Reynaud, M. (2006). Short- and long-term consequences of prenatal exposure to cannabis. Journal de Gynécologie Obstétrique et Biologie de la Reproduction, 35(1), 62 70. [DOI:10.1016/S0368-2315(06)76373-6] [PMID]

Krauzlis, R. J., Lovejoy, L. P., Zénon, A. (2013). Superior colliculus and visual spatial attention. Annual Review of Neuroscience, 36(1), 165-182. https://www.annualreviews.org/ doi/10.1146/annurev-neuro-062012-170249

Leist, M., Datunashvilli, M., Kanyshkova, T., Zobeiri, M., Aissaoui, A., \& Cerina, M., et al. (2016). Two types of interneurons in the mouse lateral geniculate nucleus are characterized by different h-current density. Scientific Reports, 6, 24904. [DOI:10.1038/ srep24904] [PMID] [PMCID]

Lester, B. M., \& Dreher, M. (1989). Effects of marijuana use during pregnancy on new-born cry. Child Development, 60(4), 765-771. [DOI:10.2307/1131016] [PMID]

Lohr, G. W., \& Waller, H. D. (1974). Glucose-6-phosphate dehydrogenase. In: H. U. Bergmeyer (Ed.), Methods of Enzymatic Analysis. (pp. 636-643). New York: Academic Press. [DOI:10.1016/B978-012-091302-2.50026-8]

Lowry, O. H., Rosebrough, N. J., Farr, A. 1., \& Randall, R. J. (1951) Protein measurement with the folin phenol reagent. Journal of Biological Chemistry, 193(1), 265-275. [DOI:10.1016/S00219258(19)52451-6] [PMID]

Mantilla-Plata, B., Clewe, G. L., \& Harbison, R. D. (1975). Delta9 Tetrahydrocannabinol-induced changes in prenatal growth and development of mice. Toxicology and applied pharmacology, 33(2), 333-340. [DOI:10.1016/0041-008x(75)90099-x] [PMID]

Marcondes, F. K., Biachi, F. J., \& Tanno, A. P. (2002). Determination of oestrous cycle phase of rats. Some helpful considerations. Brazilian Journal of Biologyl, 62(4A), 609-614. [DOI:10.1590/S151969842002000400008] [PMID]

Mereu, G., Fa, M., Ferraro, L., Cagiano, R., Antonelli, T., \& Tattoli, M., et al. (2003). Prenatal exposure to a cannabinoid agonist produces memory deficits linked to dysfunction in hippocampal long-term potentiation and glutamate release. Proceedings of the National Academy of Sciences USA, 100(8), 4915-4920. [DOI:10.1073/pnas.0537849100] [PMID] [PMCID] 
National Research Council. (2011). Guide for the care and use of laboratory animals, $8^{\text {th }}$ edition. Washington, DC: The National Academies Press. https://www.nap.edu/catalog/12910/guidefor-the-care-and-use-of-laboratory-animals-eighth

Nava, F., Cara, G., Battasi, A. M., \& Gessa, G. L. (2000). D2 dopamine receptors enable $\Delta 9$-tetrahydrocannabinol induced memory impairment and reduction of hippocampal extracellular acetylcholine concentration. British Journal of Pharmacology, 130(6), 1201-1210. [DOI:10.1038/sj.bjp.0703413] [PMID] [PMCID]

Omotoso, G. O., Akinola, O. B., Caxton-Martins, E. A., Kadir, R. E., \& Akinyinka, A. (2010). Histoenzymic effects of cigarette smoke on the superior colliculus of rattus norvegicus. The Internet Journal of Toxicology, 8(1), 32. https://www.researchgate.net/profile/Oluwole-Akinola/pub.pdf

Patrick, D. S., Krishnan, G. P., Vohs, J. L., \& O’Donnell, B. F. (2006) The effects of cannabis use and gender on visual steady-state evoked potential. Clinical Neurophysiology, 117(1), 144-156. [DOI:10.1016/j.clinph.2005.09.024] [PMID]

Prendergast, M. A., Jackson, W. J., Terry, A. V., Kille, N. J., Arneric, S. P., Decker., \& M. W. et al. (1998). Age-related differences in distractibility and response to methylphenidate in monkeys. Cerebral Cortex, 8(2),164-172. [DOI:10.1093/cercor/8.2.164] [PMID]

Santiago, L. N., Fenley, J., Braga, L. C., Cordeiro, J. A. \& Cury, P. M. (2009). The effect of different doses of cigarette smoke in a mouse lung tumor model. International Journal of Clinical and Experimental Pathology, 2(2), 176-181. [PMID] [PMCID]

Schneider, M. (2009). Cannabis use in pregnancy and early life and its consequences: Animal models. European Archives of Psychiatry and Clinical Neuroscience, 259, 383-393. [DOI:10.1007/s00406-0090026-0] [PMID]

Sherman, S.M. \& Guillery, R. W. (2004). The synaptic organization of the brain. Oxford: Oxford Scholarship [DOI:10.1093/acprof:o so/9780195159561.003.0008]

Sodeinde, O. (1992). Glucose-6-phosphate dehydrogenase deficiency. Brailness Clinical Haematology, 5(2), 367-382 [DOI:10.1016/ S0950-3536(11)80024-7] [PMID]

Suvarna, K. S., Layton, C., Bancroft, J. D. (2012). Theory and practice of histology techniques. London: Churchill Livingstone Elsevier. https://www.google.com/books/edition/Bancroft_s_Theory_and_Practice_of_Histol/ FoOn7il3yqcC?hl=en\&gbpv $=0$

Tijani, A. A., Adekomi, A. D., Oyesomi, T. O., \& Fawole, O. B. (2014). Histoarchitectural organization of the Visual system of male rats following oral administration of crude aqueous leaf of cannabis sativa. African Journal of Cellular Pathology, 2(1), 7-13. https://d1wqtxts1xzle7..net/36830710/.pdf?Exp

Trezza, V., Campolongo, P., Cassano, T., Macheda, T., Dipasquale, P., \& Carratu, M. R., et al. (2008). Effects of perinatal exposure to delta-9-tetrahydrocannabinol on the emotional reactivity of the offspring: A longitudinal behavioural study in wistar rats. Psychopharmacology (Berl), 198(4), 529-537. [DOI:10.1007/ s00213008-1162-3] [PMID]

Volkow, N. D., Baler, R. D., Compton, W. M., \& Weiss, S. R. B. (2014) Adverse health effects of marijuana use. The New England Jounal of Medicine, 370(23), 2219-2227. [DOI:10.1056/NEJMra1402309] [PMID] [PMCID]
Wei Bhaar, D., Grossau, E., \& Faderal, B. (1975). Normal ranges of alpha- HBDH, LDH, AP, LAP as measured with substrate-optimated test charges. Medizinische Welt, 26(9), 387-392. [PMID]

Wurtz, R. H. \& Goldberge, M. E. (1972). The primate superior colliculus and the shift of visual attention. Investigative Ophthalmology \& Visual Science, 11(6), 441-450. [PMID]

Yildz, D., Ercal, N., \& Armstrong, D. W. (1998). Nicotine enantiomers and oxidative stress. Toxicology, 130(2-3), 155-165. [DOI:10.1016/S0300-483X(98)00105-X] [PMID] 
This Page Intentionally Left Blank 